\title{
PENINGKATAN EFEKTIVITAS PEMASARAN JASA PERBANKAN ISLAM MELALUI PEMAHAMAN TERHADAP SEGMENTASI PELANGGAN
}

\author{
Burhanuddin Yusuf*
}

\begin{abstract}
Improving Marketing Effectiveness of Islamic Banking Services through Providing Understanding of the Customer Segmentation. There are three segments of customers in Islamic banking industry: business customers, rational customers, and religious customers. This study found that the levels of customer's satisfaction/dissatisfaction at the three segments (business, rational, and religious traveler) were differentiating by customers' perception of service quality. The business customers has a higher focus on service quality and on time performance factors. In addition, the profit sharing factor is the differentiating variable in the level of satisfaction/dissatisfaction for rational customers. The application of sharia principles is the differen-tiating variabel of religious segments.
\end{abstract}

Keywords: marketing strategy, segmentation, Islamic banking

\begin{abstract}
Abstrak: Peningkatan Efektivitas Pemasaran Jasa Perbankan Islam Melalui Pemahaman terhadap Segmentasi Pelanggan. Ada tiga segmen pelanggan dalam industri perbankan syariah: pelanggan bisnis, pelanggan rasional, dan pelanggan agama. Penelitian ini menemukan bahwa tingkat kepuasan/ ketidakpuasan pelanggan ada dalam tiga segmen (bisnis, rasional, dan wisatawan agama) yang membedakan persepsi pelanggan terhadap kualitas layanan. Para pelanggan bisnis memiliki fokus tinggi pada faktor kualitas pelayanan dan kinerja tepat waktu. Sedangkan faktor pembagian keuntungan adalah variabel pembeda dalam tingkat kepuasan/ketidakpuasan bagi pelanggan rasional. Penerapan prinsip-prinsip syariah adalah variabel pembeda dalam segmen agama.
\end{abstract}

Kata Kunci: strategi pemasaran, segmentasi, perbankan syariah

Naskah diterima: 14 Desember 2012, direvisi: 11 Maret 2013, disetujui: 21 Maret 2013.

* Fakultas Syariah dan Hukum UIN Syarif Hidayatullah Jakarta. Jl. Ir. H. Juanda 95, Ciputat, Jakarta. E-mail: bang_ibur@yahoo.com 


\section{Pendahuluan}

Pemasaran merupakan salah satu dari kegiatan pokok yang dilakukan oleh perusahaan untuk mempertahankan kelangsungan hidupnya, untuk berkembang, dan mendapatkan laba. Pemasaran seringkali dikaitkan oleh banyak pihak dengan penjualan, iklan, promosi, atau produk. Bahkan, seringkali orang menyamakan profesi marketing (pemasaran) dengan sales (penjualan). Namun sebenarnya pemasaran tidaklah sesempit yang diidentikkan banyak orang, karena pemasaran berbeda dengan penjualan. Pemasaran lebih merupakan "suatu seni menjual produk", sehingga pemasaran proses penjualan yang dimulai dari perancangan produk sampai dengan setelah produk tersebut terjual.

Berbeda dengan penjualan yang hanya berkutat pada terjadinya transaksi penjualan barang atau jasa. Dengan memahami pengertian dan fungsi pemasaran, perusahaan akan menyadari arti penting pemasaran sebagai kunci untuk mencapai tujuan, sehingga perusahaan perlu mencari konsep yang paling sesuai untuk digunakan sebagai pedoman dalam menjalankan kegiatan pemasarannya. Dalam hal ini Kotlermenyatakan, " "The marketing concept holds that the key to achieving organizational goals consist in determining the needs and wants of target markets and delivering the desired satisfactions more effectively and efficiently than competitors."

Asosiasi Pemasaran Amerika memberikan definisi formal yaitu, "Pemasaran adalah satu fungsi organisasi dan seperangkat proses untuk menciptakan, mengomunikasikan, dan menyerahkan nilai kepada pelanggan dan mengelola hubungan pelanggan dengan cara yang menguntungkan organisasi dan para pemilik sahamnya". ${ }^{2}$

Konsep pemasaran pada dasarnya terdiri atas empat pilar utama, yaitu: target market, customer needs, coordinated marketing, dan profitability. Skema yang lebih lengkap dapat dilihat pada Gambar 1.

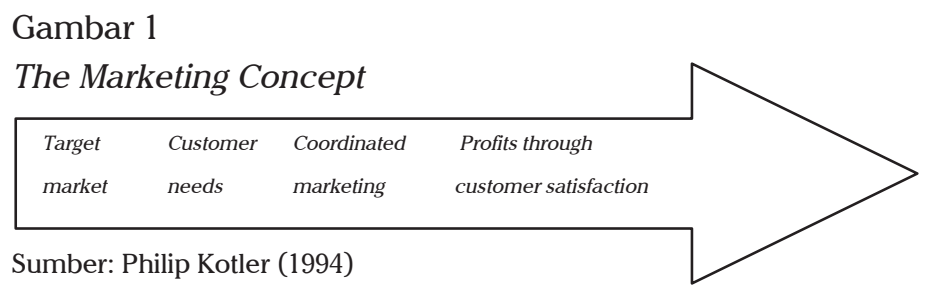

\footnotetext{
${ }^{1}$ Philip Kotler dan Kevin Lane, Manajemen Pemasaran, alih bahasa Benyamin Molan. (Ja-karta: Indeks, 2007).

${ }^{2}$ Philip Kotler dan AB Susanto, Manajemen Pemasaran di Indonesia, (Jakarta: Salemba Em-pat, 2000).
} 
Konsep pemasaran muncul pada pertengahan tahun 1950-an. Sebagai ganti filosofi "buat dan jual" yang berpusat pada produk, bergeser ke filosofi "pahami dan tanggapi" yang berpusat pada konsumen. Filosofi "buat dan jual" bertitik tolak bahwa konsumen akan membeli seluruh barang yang diproduksi oleh perusahaan, namun kelemahan dari filosofi ini adalah seringkali produk yang dibuat perusahaan tidak terserap oleh pasar, karena produk yang dibuat tidak berdasarkan kebutuhan dan keinginan konsumen. Hal ini mengakibatkan banyaknya produk perusahaan yang tidak laku di pasaran, meskipun betapa canggih dan bagusnya produk tersebut karena tidak sesuai dengan kebutuhan dan keinginan masyarakat.

Sementara filosofi "pahami dan tanggapi" bertitik tolak bahwa pembuatan suatu produk haruslah berdasarkan apa yang menjadi kebutuhan dan keinginan dari konsumen, sehingga produk yang dibuat benar-benar yang menjadi kebutuhan konsumen. Riset pasar menjadi kunci utama dalam filosofi ini, agar pembuatan produk benar-benar berdasarkan pada kebutuhan dan keinginan konsumen. Seorang pemasar mampu memahami pelanggan secara emosi, sehingga kebutuhan dan keinginan konsumen dapat dipahami oleh pemasar dan akhirnya mampu menghasilkan produk yang dibutuhkan oleh konsumen. Konsep pemasaran menegaskan bahwa kunci untuk mencapai tujuan organisasi yang ditetapkan adalah perusahaan tersebut harus menjadi lebih efektif dibandingkan para pesaing dalam menciptakan, menyerahkan, dan mengomunikasikan nilai pelanggan kepada pasar sasaran yang terpilih.

Tabel 1

Perbedaan Karakteristik Barang dan Jasa ${ }^{3}$

\begin{tabular}{|c|c|c|}
\hline Barang & Jasa & Implikasi \\
\hline Tangible & Intangible & $\begin{array}{l}\text { - Services cannot be inventoried } \\
\text { - Services cannot be patented } \\
\text { - Services cannot be readily displayed or } \\
\text { communicated } \\
\text { - Pricing of services is difficult }\end{array}$ \\
\hline Standardized & Heterogenous & $\begin{array}{l}\text { - Services delivery and customer } \\
\text { satisfaction depend on employee } \\
\text { actions } \\
\text { - Service quality depends on many } \\
\text { uncontrollable factors } \\
\text { - There is sure knowledge that the service } \\
\text { delivered matches what was planned }\end{array}$ \\
\hline
\end{tabular}

${ }^{3}$ Valarie A. Zeithaml and Mary Jo Bitner, "Services Marketing", 1996, h. 18-19. 


\begin{tabular}{lll}
\hline & & and promoted \\
\hline Production & Simultaneous & - Customers participate in and affect the \\
separate from & production and & transaction \\
consumption & consumption & - Customers affect each other \\
& & - Employees affect the service outcome \\
& & - Decentralization may be essential \\
& & - Mass production is difficult \\
\hline Nonpersihable & Perishable & - It is difficult to synchronize suplly and \\
& & demand with services \\
& & - Services cannot be returned or resold \\
\hline
\end{tabular}

Sumber: Valarie A. Zeithaml and Mary Jo Bitner

Konsep pemasaran memiliki orientasi kepada konsumen, sehingga semua strategi pemasaran harus disusun berdasarkan kebutuhan dan keinginan konsumen. Tanpa pema-haman mengenai perilaku konsumen, strategi pemasaran dengan menggunakan konsep pemasaran tidak akan dapat disusun, sehingga tidak akan mampu memenuhi kebutuhan dan keinginan konsumen dan mencapai tujuan ekonomi perusahaan. Dalam prakteknya, konsep pemasaran mengalami perkembangan yang demikian pesat, seiring dengan semakin majunya teknologi, tingkat kehidupan masyarakat, dan lingkungan yang semakin dinamis.

Produk yang dihasilkan di bidang jasa sangat berbeda dengan produk dalam bentuk fisik. Perbedaan yang mendasar antara produk dan jasa menyebabkan strategi pemasaran yang digunakan juga akan berbeda. Pemasaran jasa akan menghadapi tantangan. Tantangan ini berhubungan dengan pemahaman mengenai keinginan dan harapan konsumen terhadap jasa yang ditawarkan, menawarkan jasa yang tidak nyata menjadi nyata, dan memenuhi janji kepada pelanggan. Beberapa perbedaan dan implikasinya dalam bidang pemasaran dapat dilihat pada tabel 1 .

Pemasaran yang dilakukan oleh perbankan adalah konsep pemasaran jasa. Pada dasarnya pengertian konsep pemasaran mempunyai persamaan dengan konsep pemasaran bank. Konsep pemasaran (produksi) berorientasi pada kebutuhan konsumen, sedangkan konsep pemasaran berorientasi pada konsumen (nasabah). Dasar pemikirannya bagaimana caranya aktivitas pemasaran bank dapat dilaksanakan berdasarkan suatu falsafah yang mantap, yang mengungkapkan pemasaran yang tanggap, bertanggung jawab dan selalu memberikan kepuasan pada nasabah serta menguntungkan perusahaan. Dibandingkan dengan strategi pemasaran suatu produk, strategi pemasaran jasa tidaklah cukup dengan menggunakan traditional marketing approach. Menurut Groon- 
roos, dalam pemasaran jasa dibutuhkan tiga jenis pemasaran, yaitu: internal marketing, external marketing, dan inter-active marketing ${ }^{4}$.

Gambar 2

Three Types of Marketing in Service Industries

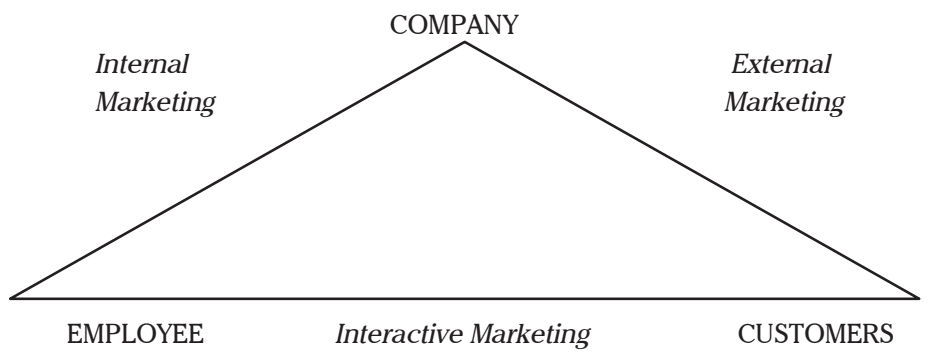

Sumber: Philip Kotler: 1994

External marketing adalah bagaimana perusahaan menetapkan harga, distribusi, dan mempromosikan jasa kepada pelanggan. Internal marketing berkaitan dengan bagaimana perusahaan melatih dan memotivasi internal customer perusahaan, yaitu karyawan peru-sahaan agar dapat melayani pelanggan dengan baik. Interactive marketing adalah bagaimana kemampuan karyawan menguasai bidangnya dalam menghadapi pelanggan. Kemampuan pekerja ini merupakan ujung tombak perusahaan dalam menjual jasanya. Karena karak-teristik jasa yang juga berbeda, maka elemen kontrol perusahaan yang digunakan untuk memuaskan dan berkomunikasi dengan konsumen (dikenal dengan variabel marketing mix) memerlukan modifikasi jika diterapkan dalam pemasaran jasa. Pengembangan strategi marketing mix dalam jasa memerlukan tambahan tiga elemen lagi selain elemen tradisional yang biasa (product, place, promotion, and price), yaitu: people, physical evidence, dan process. $^{5}$

\section{Konsep Perbankan Islam}

Dalam Undang-Undang No. 21 Tahun 2008 tentang Perbankan Syariah diterangkan bahwa yang dimaksud dengan perbankan syariah adalah segala sesuatu yang menyangkut tentang Bank Syariah dan Unit Usaha Syariah, mencakup kele-

\footnotetext{
${ }^{4}$ Philip Kotler, Marketing Management: Analysis, Planning, Implementation and Control 8th edition, (Englewood Cliffs, NJ: Prentice Hall International, 1994).

${ }^{5}$ Zeithaml VA, Bitner MJ, Services Marketing. (1th ed), (New York: The McGraw-Hill Companies. Inc., 1996)
} 
mbagaan, kegiatan usaha, serta cara dan proses dalam melaksanakan kegiatan usahanya.

Dari definisi perbankan syariah di atas ada dua kelembagaan yang terdapat pada perbankan syariah yaitu Bank Syariah dan Unit Usaha Syariah. Munculnya dua kelembagaan ini pada perbankan syariah di Indonesia terkait dengan dual banking system yang dianut pada sistem perbankan di Indonesia.

Menurut Undang-Undang No. 21 tahun 2008, bank Syariah adalah bank yang menjalankan kegiatan usahanya berdasarkan prinsip syariah dan menurut jenisnya terdiri atas Bank Umum Syariah dan Bank Pembiayaan Rakyat Syariah. Sementara Unit Usaha Syariah menurut Undang-Undang ini adalah unit kerja dari kantor pusat bank umum konvensional yang berfungsi sebagai kantor induk dari kantor atau unit yang melaksanakan kegiatan usaha berdasarkan prinsip syariah, atau unit kerja di kantor cabang dari suatu bank yang berkedudukan di luar negeri yang melaksanakan kegiatan usaha secara konvensional yang berfungsi sebagai kantor induk dari kantor cabang pembantu syariah dan/atau unit syariah.

Bank Islam bukan hanya bank bebas bunga, namun memiliki orientasi pencapaian sejahtera. Secara fundamental terdapat beberapa karakteristik bank syariah, ${ }^{6}$ yakni: (1) penghapusan riba; (2) Pelayanan kepada kepentingan publik dan merealisasikan sasaran sosio-ekonomi Islam; (3) Bank syariah bersifat universal yang merupakan gabungan dari bank komersial dan bank investasi; (4) Bank syariah akan melakukan evaluasi yang lebih berhati-hati terhadap permohonan pembiayaan yang berorientasi kepada penyertaan modal, karena bank komersial syariah menerapkan profit-loss sharing dalam konsinyasi, ventura, bisnis, atau industri; (5) Bagi hasil cenderung mempererat hubungan antara bank syariah dan pengusaha; (6) Kerangka yang dibangun dalam membantu bank mengatasi likuiditasnya dengan memanfaatkan instrument pasar uang antar bank syariah dan instrument bank sentral berbasis syariah.

\section{Pemasaran Jasa Perbankan}

Pada dasarnya pengertian konsep pemasaran mempunyai persamaan dengan konsep pemasaran bank. Konsep pemasaran (produksi) berorientasi pada kebutuhan konsumen, sedangkan konsep pemasaran berorientasi pada konsumen (nasabah). Dasar pemikirannya bagaimana caranya aktivitas pemasaran bank dapat dilaksanakan berdasarkan suatu falsafah yang mantap, yang mengungkapkan pemasaran yang tanggap, bertanggung jawab dan selalu memberikan kepuasan pada nasabah serta menguntungkan perusahaan.

\footnotetext{
${ }^{6}$ Andri Soemitra, Bank dan Lembaga Keuangan Syariah, (Jakarta: Kencana Prenada Media, 2009).
} 
Konsep pemasaran bank mengandung arti: (1) Mempunyai falsafah yang mantap dan bertanggung jawab; (2) Berorientasi pada nasabah di satu pihak; (3) Menguntungkan perusahaan di lain pihak ${ }^{7}$.

Secara umum tujuan pemasaran bank adalah: Pertama, memaksimumkan konsumsi atau dengan kata lain memudahkan dan merangsang konsumsi, sehingga dapat menarik nasabah untuk membeli produk yang ditawarkan bank secara berulang-ulang. Kedua, memaksimumkan kepuasan pelanggan melalui pelbagai pelayanan yang diinginkan nasabah. Nasabah yang puas akan menjadi ujung tombak pemasaran selanjutnya, karena kepuasan ini akan ditularkan kepada nasabah lainnya melalui cerita (word of mouth). Ketiga, memaksimumkan pilihan (ragam produk) dalam arti bank menyediakan pelbagai jenis produk bank sehingga nasabah memiliki beragam pilihan pula. Keempat, memaksimumkan mutu hidup dengan memberikan pelbagai kemudahan kepada nasabah dan menciptakan iklim yang efisien. ${ }^{8}$

Kepuasan pelanggan dalam dunia perbankan harus diartikan secara komprehensif. Artinya, nasabah akan merasa sangat puas bila komponen kepuasan tersebut dapat terpenuhi secara lengkap. Berikut ini kepuasan nasabah dalam dunia perbankan. Pertama, tangibles. Merupakan bukti fisik yang harus dimiliki oleh karyawan bank, seperti gedung, perlengkapan kantor, daya tarik karyawan, sarana komunikasi, dan sarana fisik lainnya. Kedua, responsitivitas. Adanya keinginan dan kemauan karyawan bank dalam memberikan pelayanan kepada pelanggan. Untuk itu pihak manajemen bank perlu memberikan motivasi yang besar agar seluruh karyawan bank mendukung kegiatan pelayanan kepada nasabah dengan baik. Ketiga, assurance. Jaminan bahwa karyawan memiliki pengetahuan, kompetensi, kesopanan, dan sifat atau perilaku yang dapat dipercaya. Hal ini penting agar nasabah yakin akan transaksi yang mereka lakukan benar dan tepat sasaran. Keempat, reliabilitas. Kemampuan bank dalam memberikan pelayanan yang telah dijanjikan dengan cepat, akurat serta memuaskan pelanggannya. Guna mendukung hal ini maka setiap karyawan bank sebaiknya diberikan pelatihan dan pendidikan guna meningkatkan kemampuannya. Kelima, emphaty. Mampu memberikan kemudahan serta menjalin hubungan dengan nasabah secara efektif. Kemudian juga mampu memahami kebutuhan individu setiap nasabahnya secara cepat, tepat, dan akurat. Dalam hal ini masalah prosedur kerja dan dihubungkan dengan tingkat pelayanan kepada nasabah.

${ }^{7}$ Herry Achmad Buchory dan Djaslim Saladin, Dasar-dasar Pemasaran Bank, (Bandung: Linda Karya, 2006).

${ }^{8}$ Kasmir, Pemasaran Bank, (Jakarta: Kencana, 2004). 


\section{Segmentasi Pasar}

Pasar untuk produk jasa perbankan sangatlah luas, sehingga perusahaan atau bank tidak mudah untuk memasuki pasar yang sedemikian luas dan kalaupun bisa kemungkinan berhasil sangatlah kecil. Pasar yang luas ini perlu untuk dipilah-pilah agar mempermudah perusahaan dalam melakukan kegiatan pemasarannya. Karena pasar yang luas maka sebelum melakukan kegiatan pemasaran produk harus dilakukan terlebih dahulu riset pasar, yang bertujuan untuk mengetahui seberapa besar pasar yang akan dimasuki, siapa yang menjadi konsumen produk tersebut dan seberapa besar kompetitor.

Tingkat kompetisi pemasaran bank semakin ketat, masing-masing perusahaan (bank) harus semakin jeli dalam memilih pasar sasarannya agar memiliki keunggulan kompetitif dalam memasarkan produk-produknya. Segmentasi pasar semakin penting dan merupakan salah satu kunci yang menentukan sukses atau tidak suatu perusahaan (bank). Kotler memberikan definisi segmentasi sebagai berikut, "Segmentation is process partitioning markets into groups of potential customers with similar needs and characteristics who are likely to exhibit similar purchase behavior". 9

Selanjutnya Kotler, Kertajaya, Huan, dan Liu menyatakan bahwa segmentasi adalah melihat pasar secara kreatif, segmentasi merupakan seni mengidentifikasi dan memanfaatkan peluang-peluang yang muncul di pasar. Pada saat yang sama segmentasi merupakan ilmu (science) untuk memandang pasar berdasarkan variabel geografis, demografis, psiko-grafis, dan perilaku.

Berdasarkan pengertian diatas dapat disimpulkan bahwa segmentasi memiliki peran penting dalam sebuah perusahaan karena beberapa alasan. ${ }^{10}$ Pertama, segmentasi memungkin perusahaan untuk lebih fokus dalam mengalokasikan sumber daya. Dengan membagi pasar menjadi segmen-segmen akan memberikan gambaran bagi perusahaan untuk menetapkan segmen mana yang akan dilayani. Selain itu segmentasi memungkin perusahaan mendapatkan gambaran yang lebih jelas mengenai peta kompetisi serta menentukan posisi pasar perusahaan. Kedua, segmentasi merupakan dasar untuk menentukan komponen-komponen strategi. Segmentasi yang disertai dengan pemilihan target market akan memberikan acuan dalam penentuan positioning. Ketiga, segmentasi merupakan faktor kunci untuk mengalahkan pesaing, dengan memandang pasar dari sudut yang unik dan cara yang berbeda dari yang dilakukan pesaing.

\footnotetext{
${ }^{9}$ Philip Kotler dan AB Susanto, Manajemen Pemasaran di Indonesia, (Jakarta: Salemba Empat, 2000).

${ }^{10}$ Kasmir, Pemasaran Bank, (Jakarta: Kencana, 2004).
} 
Sehingga segmentasi dapat diartikan sebagai suatu kegiatan membagi suatu pasar menjadi kelompok-kelompok pembeli yang berbeda yang mungkin memerlukan produk atau ramuan pemasaran tersendiri. Bank dalam menjual produknya ke nasabah membagi pasar menjadi beberapa jenis sesuai dengan kriteria yang diinginkan. Pembagian pasar akan memudahkan bank dalam menentukan nasabah atau konsumen sasarannya. Segmentasi pasar perlu dilakukan karena pada umumnya pasar untuk suatu produk atau jasa mempunyai banyak perbedaan terutama pada kebutuhan, keinginan dan daya beli.

Segmentasi pasar perlu dilakukan karena pada umumnya pasar untuk suatu produk atau jasa mempunyai banyak perbedaan terutaman pada kebutuhan, keinginan, dan daya beli. Dengan melakukan segmentasi pasar, perusahaan akan lebih mudah melayani pelbagai kebutuhan dan keinginan pasar tersebut. Selain itu segmentasi perlu dilakukan disebabkan di dalam suatu pasar terdapat banyak pembeli yang berbeda keinginan dan kebutuhannya. Setiap perbedaan memiliki potensi untuk menjadi pasar tersendiri. Dalam melakukan segmentasi diperlukan variabel atau pertimbangan yang perlu diperhatikan. Pemasar tidak menciptakan segmen, tugas pemasar adalah mengidentifikasi segmen dan memutuskan mana yang dibidik. Segmentasi pasar memberikan manfaat yang besar bila dibandingkan dengan pemasaran massal. Perusahaan dapat merancang, menetapkan harga, menying-kapkan dan menyerahkan produk atau jasa secara lebih untuk memuaskan pasar sasaran. Perusahaan juga dapat membuat program dan kegiatan pemasaran untuk mencerminkan pemasaran pesaing.

Dalam melakukan segmentasi pasar, terdapat beberapa cara. Segmentasi dapat dilakukan berdasarkan geografis, demografis, psikografis, dan perilaku yang dapat digunakan secara tersendiri atau gabungan. Secara garis besarnya, dasar-dasar segmentasi pasar dijelaskan sebagai berikut: Pertama, orang dengan keinginan: segmentasi dapat dilakukan menurut dasar geografis dan demografis. Kedua, adanya uang untuk dibelanjakan: segmentasi dilakukan berdasarkan daya beli konsumen (distribusi pendapatan). Ketiga, kemauan untuk membelanjakan. Segmentasi dilakukan dengan melihat perilaku beli konsumen.

Di samping mengacu pada beberapa dasar segmentasi di atas pemasar dapat melakukan pembedaan segmentasi preferensi. Tiga pola yang berbeda dapat muncul. Pertama, preferensi homogen (homogenous preference), merupakan pola yang menunjukkan bahwa konsumen memiliki preferensi yang sama terhadap produk atau jasa yang ditawarkan, menunjukkan suatu pasar dimana semua konsumen secara umum memiliki preferensi yang sama. Kedua, preferensi yang tersebar (diffused preference), merupakan pola yang menunjukkan bahwa konsumen memiliki preferensi yang beragam terhadap suatu produk atau jasa 
yang ditawarkan. Ketiga, preferensi terkelompok (cluster preference), merupakan pola yang menunjukkan bahwa konsumen memiliki preferensi yang berkelompok-kelompok. Di mana konsumen yang berada dalam satu kelompok memiliki kesamaan preferensi.

\section{Implikasi terhadap Pemasaran Jasa Perbankan Islam di Indonesia}

Konsep segmentasi pada jasa perbankan Islam akan memberikan implikasi penting pada strategi pemasaran jasa perbankan Islam di Indonesia. Karena pada setiap kelompok yang terdapat pada segmentasi tersebut diperlukan strategi pemasaran yang berbeda-beda. Karakteristik konsumen yang berbeda akan memerlukan perlakuan pemasaran yang berbeda-beda agar strategi pemasaran yang dilaksanakan dapat efektif.

Berdasarkan perkembangan perbankan Islam di Indonesia yang telah dimulai semenjak tahun 1992 sampai dengan sekarang, setidaknya ada tiga segmen nasabah yang dapat dikategorikan dalam pemasaran jasa perbankan Islam dimana masing-masing segmen nasabah memiliki sudut pandang yang berbeda mengenai kualitas pelayanan perbankan yang diterima. Pertama, segmen nasabah bisnis. Bagi segmen nasabah bisnis, yang diutamakan dalam pelayanan jasa perbankan Islam adalah dari aspek kualitas pelayanan dan waktu pelayanan. Pelbagai macam fasilitas perbankan yang dibutuhkan untuk menunjang aktivitas bisnisnya sangat dicari. Sehingga strategi pemasaran yang tepat untuk nasabah segmen ini adalah dengan memberikan pelbagai macam fasilitas yang dapat menunjang aktivitas bisnisnya. Sebagai contoh adalah fasilitas mobilebanking, internet banking, ATM, layanan prioritas, produk pembiayaan dengan bagi hasil yang kompetitif baik dengan sesama bank Islam ataupun bank konvensional. Bagi nasabah segmen ini harus mendapatkan perlakuan yang lebih dibandingkan dengan nasabah biasa.

Kedua, segmen nasabah rasional. Segmen nasabah rasional sangat berorientasi pada besaran bagi hasil yang diterimanya. Mereka menabung di bank Islam dengan memperbandingkan berapa besaran persentase bagi hasil di bank Islam dengan tingkat suku bunga di bank konvensional. Dengan selisih sekitar dua persen (dari tingkat bunga bank konvensional), segmen nasabah ini masih loyal di bank Islam, tetapi lebih dari itu, segmen nasabah ini bisa berpindah ke bank konvensional.

Berdasarkan statistika pada triwulan ketiga tahun 2005 tren meningkatnya suku bunga berdasarkan analisis BI juga sempat membuat perbankan Islam menghadapi risiko pengalihan dana (dari bank Islam ke bank konvensional). Diperkirakan lebih dari Rp 1 triliun dana nasabah dialihkan pada triwulan ketiga 
tahun 2005. Namun, kepercayaan deposan pada perbankan Islam terbukti dapat dipulihkan dengan pertumbuhan dana pihak ketiga yang mencapai Rp 2,2 triliun pada akhir tahun. Perbankan Islam harus mampu menawarkan tingkat bagi hasil yang kompetitif kepada nasabahnya baik kepada nasabah deposan maupun nasabah pembiayaan. Sebab apabila tingkat bagi hasilnya terlalu jauh, maka nasabah akan banyak yang berpindah dari perbankan Islam ke perbankan konvensional.

Ketiga, segmen nasabah religius. Sementara untuk segmen nasabah terakhir adalah segmen nasabah religius, dimana pada segmen nasabah ini pelaksanaan prinsip-prinsip syariah dalam operasional perbankan sangat diutamakan. Nasabah ini tidak terpengaruh kepada besaran bagi hasil yang diterima apakah lebih besar ataukah lebih kecil daripada sesama bank Islam ataupun dengan bank konvensional. Yang terpenting bagi segmen masyarakat ini adalah dengan bertransaksi pada perbankan Islam disamping lebih memudahkan transaksi ekonomi mereka pun akan terhindar dari riba yang terdapat pada bank konvensional.

Perbankan Islam harus terus meningkat purifikasi praktik operasional perbankan Islam yang benar-benar sesuai dengan konsep syariah. Penyimpangan dari konsepsi bank Islam akan menghilangkan jati diri dan keunikan bank Islam, yang pada gilirannya akan menghilangkan eksistensi bank Islam. Saat ini masih ada kecenderungan kekecewaan pengguna jasa perbankan Islam karena masih ada praktik-praktik yang dinilai tidak sejalan dengan prinsip syariah, sehingga berakibat loyalitas dan kontinuitas penggunaan jasa bank tersebut tidak dapat dipertahankan lama. Penyimpangan prinsip syariah dapat terjadi dalam pelbagai derajat, misalnya hanya yang sekadar melakukan benchmarking tingkat bagi hasil atau marjin jual beli dengan tingkat bunga bank konvensional yang berlaku hingga penempatan dana menganggur pada bank-bank konvensional dengan motif memperoleh pendapatan bunga.

\section{Penutup}

Segmentasi merupakan salah satu cara yang dilakukan oleh perusahaan dalam strategi pemasarannya, hal ini dilakukan karena pasar sangat luas sehingga perlu dilakukan pemilahan terhadap pasar. Dengan melakukan segmentasi pasar, maka perusahaan akan lebih mudah dalam menetapkan strategi pemasaran yang akan digunakan untuk mencapai tujuan perusahaan.

Pada perbankan Islam, setidaknya ada tiga segmen nasabah yang memiliki sudut pandang yang berbeda mengenai kualitas pelayanan jasa perbankan Islam yang diterima. Pertama, segmen nasabah bisnis, yaitu nasabah yang menguta- 
makan kualitas pelayanan dan waktu pelayanan. Kedua, segmen nasabah rasional, yaitu nasabah yang mengutamakan keuntungan jangka pendek yang ditawarkan berupa besaran bagi hasil yang diterima dibandingkan dengan sesama bank Islam maupun dengan bank konvensional. Ketiga, segmen nasabah religius, yaitu nasabah yang mengutamakan praktik operasional perbankan Islam yang sesuai dengan syariah.

Masing-masing segmen nasabah ini memerlukan strategi pemasaran yang berbeda-beda. Diharapkan dengan mengetahui karakteristik masing-masing, perbankan Islam dapat merancang strategi pemasaran yang tepat bagi masing-masing segmen tersebut. []

\section{Pustaka Acuan}

Alma, Buchari, Manajemen Pemasaran dan Pemasaran Jasa, Bandung: Alfabeta, 2004.

Al Arif, M. Nur Rianto, Dasar-dasar Pemasaran Bank Syariah, Bandung: Alfabeta, 2010.

Antonio, M. Syafii, Bank Syariah: Teori dan Praktik. Jakarta: Gema Insani Press, 2001.

Barata, Atep Adya, Dasar-dasar Pelayanan Prima, Jakarta: Elex Media Komputindo, 2003.

Buchory, Herry Achmad dan Djaslim Saladin, Dasar-dasar Pemasaran Bank, Bandung: Linda Karya, 2006.

Karim, Adiwarman Azwar, Bank Islam: Analisis Fiqh dan Keuangan, Jakarta: Rajawali Press, 2004.

Kasmir, Pemasaran Bank, Jakarta: Kencana, 2004.

Kotler, Philip, Marketing Management: Analysis, Planning, Implementation and Control 8th edition. Englewood Cliffs, NJ: Prentice Hall International, 1994.

Marketing Management, The Millennium Edition. New Jersey: Prentice Hall, 2000.

, dan AB Susanto, Manajemen Pemasaran di Indonesia. Jakarta: Salemba Empat, 2000.

--------------, dan Kevin Lane, Manajemen Pemasaran, alih bahasa Benyamin Molan, Jakarta: Indeks, 2007.

Perwaatmadja, Karnaen dan Muhammad Syafii Antonio, Apa dan Bagaimana Bank Islam, Yogyakarta: Dana Bhakti Prima Yasa, 1992.

Soemitra, Andri, Bank dan Lembaga Keuangan Syariah, Jakarta: Kencana Prenada Media, 2009. 